References

Catovsky, D., Ikoku, N. B., Pitney, W. R., and Galton, D. A. G. (1970). British Medical fournal, 3, 438 .

Clarkson, A. R., MacDonald, M. K., Fuster, V., Cash, J. D., and Robson, J. S. (1970). Quarterly fournal of Medicine, 39, 585 .

Clarkson, A. R., MacDonald, M. K., Petrie, J. J. B., Cash, J. D., Robson, J. S. (1971). British Medical fournal, 3, 447.
Hobbs, J. R., (1971). Personal communication.

Lackner, H., Hunt, V., Zucker, M. B., and Pearson, J. (1970). British Fournal of Haematology, 18, 625

Medical Research Council. (1973). British fournal of Haematology, 24, 123.

Peto, R. (1971). British Medical fournal, 2, 324.

Preston, F. E., and Lee D. (1972). Acta Haematologica, 47, 65.

Vigliano, E. M., and Horowitz, H. I. (1967). Blood, 29, 823.

\title{
Trophic Skin Ulceration of Leprosy: Skin and Serum Zinc Concentrations
}

\author{
BENG BEE OON, KIT YEW KHONG, MALCOLM W. GREAVES, VALERIE M. PLUMMER
}

British Medical fournal, 1974, 2, 531-533

\section{Summary}

Skin and serum zinc measurements have been made in patients with leprosy with and without trophic skin ulceration and in several other groups. Serum zinc concentrations were decreased in leprosy irrespective of the presence or absence of skin ulceration. Serum zinc concentrations in leprosy were also unrelated to smears positive for Mycobacterium leprae and to the clinical type of leprosy. Since a decrease of the serum zinc was also found in patients with dermatitis herpetiformis and pulmonary tuberculosis it seems likely that the decreased serum zinc in leprosy is a nonspecific metabolic consequence of chronic skin and internal disease. The mean skin zinc concentration in leprosy did not differ significantly from the corresponding value in control subjects, the lack of agreement between serum and skin concentrations being possibly related to the presence of nonexchangeable keratin-bound zinc in skin. Though the clinical significance of lowered serum zinc concentrations in leprosy is uncertain therapeutic trials of zinc treatment in leprosy with trophic skin ulceration seem justifiable.

\section{Introduction}

The association between chronic skin ulceration from different causes and lowered plasma or serum zinc concentrations has been shown in several studies (Greaves and Boyde, 1967; Withers et al., 1968; Halstead and Smith, 1970; Serjeant et al., 1970; Hallbook and Lanner, 1972). There is also evidence that supplementation of dietary zinc may promate the healing of ulcers in patients with low plasma or serum zinc concentrations (Husain, 1969; Serjeant et al., 1970; Hallbook and Lanner, 1972). In leprosy chronic indolent plantar or trophic ulceration is a common cause of disability. We have therefore investigated skin and serum zinc concentrations in patients with leprosy and skin ulceration and in several control groups.

Trafalgar Home, Yio Chu Kang Road, Singapore BENG BEE OON, M.B., M.R.C.P., Medical Superintendent KIT YEW KHONG, L.M.S.S.A., Medical Officer

University Department of Dermatology, Royal Victoria Infirmary, Newcastle upon Tyne NE1 4LP

MALCOLM W. GREAVES, M.D., M.R.C.P., Reader in Dermatology

VALERIE M. PLUMMER, Research Technician

\section{Patients and Methods}

Altogether 93 subjects were studied. Of these, 39 were leprosy inpatients, 21 aged 27-74 years with chronic skin ulceration (five of whom gave smears positive for Mycobacterium leprae) and 18 aged 20-68 years with no ulceration (11 of whom gave smears positive for $M$. leprae); 16 aged 19-71 years were inpatients with ohronic pulmonary tuberculosis receiving chemotherapy; 33 aged 17-74 years were attending hospital as outpatients with minor genitourinary and skin ailments (these patients serving as healthy controls); and 5 aged 34-65 years with dermatitis herpetiformis were outpatients receiving 100$200 \mathrm{mg}$ dapsone daily. All the leprosy patients were on dapsone treatment at the Trafalgar Home Leprosarium, Singapore. The inpatient groups were receiving similar diets which were nutritionally adequate. Fully informed consent for the investigation was obtained from all the patients.

For the skin zinc determinations six 4-mm full-thickness punch biopsy specimens were removed from the upper and outer aspect of the thigh using a stainless steel, electrically driven, high-speed rotary drill (Shuster and Bottoms, 1963). This procedure is almost painless and obviates the need for local anaesthesia. Great care was taken not to overstretch the skin. The specimens were stored in a sealed polyethylene tube before analysis. A digest of the six specimens was prepared by the method of Harrison et al. (1968). The specimens were rinsed in $10 \%$ formaldehyde (reagent grade, zinc free) to remove any blood contamination, oven-dried overnight, weighed and transferred to a volumetric flask for digestion. Wet digestion was then carried out using nitric acid and perchloric acid (Hopkins and Williams Ltd., atomic absorption grade). The volume of the final digest was $1.6 \mathrm{ml}$. Digests were diluted to $20 \mathrm{ml}$ with deionized water before analysis of the zinc concentration. To prevent zinc contamination during handling of the skin samples and digests stainless steel instruments were used to transfer the specimens to the zinc-free polyethylene containers and all glassware was rendered zinc-free by soaking overnight in ethylenediamine tetra-acetic acid and rinsing in deionized water.

Zinc analysis was carried out using a Unicam SP 1950 atomic absorption spectrophotometer with an air-acetylene flame. The multi-slot burner was coated with plastic to prevent acid corrosion. Standand curves $(5,10,25$, and $50 \mu \mathrm{g} /$ $100 \mathrm{ml}$ ) were obtained by using a standard zinc solution (1 $\mathrm{mg} / \mathrm{ml}$, B.D.H.) diluted with deionized water. A direct concentration readout was used. Reproducible readings were obtained from solutions containing less than $10 \mu \mathrm{g} \mathrm{zinc} / 100 \mathrm{ml}$. Reagent blanks were unrecordable. Results expressed in terms of dry weight of skin may be unsatisfactory since though the zinc content of the skin is mainly epidermal (Molokhia and Pontnoy, 1969) dermal thickness varies greatly between individuals. Results were therefore also calculated in terms of 
surface area, since the surface area of all specimens was equal and was accurately defined and is a satisfactory fixed reference point (Shuster et al., 1967). In practice these results were expressed per 4-mm diameter specimen. There was good agreement between results expressed by the two methods in almost all experiments.

Serum zinc analyses were carried out on morning venous blood samples using zinc-free plastic disposable syringes and stainless steel needles. The blood was allowed to clot and then centrifuged. The supernatant serum was separated by decantation and stored, haemolysed samples being rejected. Zinc-free polyethylene containers were used throughout. The method for analysis of serum zinc was identical with that used for skin zinc with the following exceptions. Standard curves were obtained with $25,50,100$, and $150 \mu \mathrm{g} / 100 \mathrm{ml}$ standard zinc solutions. To exclude error due to differences in the viscosity of the samples estimations were carried out on several dilutions of the serum. The results invariably agreed closely. All zinc analyses both on serum and skin digest samples were carried out blind.

Mean Serum Zinc Concentrations ( \pm S.E. of Mean) in the Five Groups of Subjects

\begin{tabular}{rl|c|c|c}
\hline \multicolumn{2}{c|}{ Clinical Group } & $\begin{array}{c}\text { No. of } \\
\text { Subjects }\end{array}$ & $\begin{array}{r}\text { Serum Zinc } \\
(\mu \mathrm{g} / 100 \mathrm{ml})\end{array}$ & $\mathrm{P} *$ \\
\hline Leprosy and ulceration & $\ldots$ & 21 & $89 \cdot 9 \pm 4 \cdot 0$ & $<0 \cdot 02$ \\
Leprosy, no ulceration & $\ldots$ & 18 & $89 \cdot 8 \pm 4 \cdot 6$ & $<0 \cdot 02$ \\
Pulmonary tuberculosis & $\ldots$ & 16 & $85 \cdot 0 \pm 3 \cdot 9$ & $<0 \cdot 005$ \\
Dermatitis herpetiformis & $\ldots$ & 5 & $86 \cdot 9 \pm 3 \cdot 1$ & $<0 \cdot 005$ \\
Control &. & 33 & $102 \cdot 4 \pm 3 \cdot 0$ & \\
\hline
\end{tabular}

* Significance of difference from control value.

\section{Results}

Serum Zinc.-The mean serum zinc concentrations for the five groups of subjects are shown in the table. Values for the leprosy patients were significantly reduced when compared with those for the healthy control group irrespective of the presence of skin ulceration $(0.02>\mathrm{P}>0.01$ for both leprosy groups). Neither the clinical type of leprosy (tuberculoid, borderline, or lepromatous) nor the presence of a smear positive for $M$. leprae influenced the serum zinc. Zinc is bound to serum protein (Prasad and Oberleas, 1970; Caughey, 1973), and the mean serum albumin in 27 patients with leprosy was low (3.45 g, range $2 \cdot 8-4.3 \mathrm{~g} / 100 \mathrm{ml}$ ) compared with published normal values $(4.04 \mathrm{~g}$, range $3.50-4.58 \mathrm{~g} / 100 \mathrm{ml}$ ) (Documenta Geigy, 1970). There was no correlation, however, between the concentrations of albumin and zinc in the serum of the 27 leprosy patients $(r=0.09)$. The 27 patients were divided into two groups, 13 with a serum zinc above $90 \mu \mathrm{g} / 100 \mathrm{ml}$ and 14 with values below this. The mean serum albumin $( \pm$ S.E. of mean) was almost identical in the two groups (3.44 \pm 0.06 $\mathrm{g} / 100 \mathrm{ml}$ and $3.46 \pm 0.12 \mathrm{~g} / 100 \mathrm{ml}$ respectively). The mean serum zinc of the patients with pulmonary tubenculosis was lower than that of the leprosy group and was comparable to the mean obtained in the few patients with dermatitis herpetiformis, all of whom were receiving dapsone 100-200 mg daily (pulmonary tuberculosis group 85.0 $\pm 3.9 \mu \mathrm{g} / 100 \mathrm{ml}$ and dermatitis herpetiformis group $86.9 \pm 3 \cdot 1 \mu \mathrm{g} / 100 \mathrm{ml}$ ). The mean serum zinc was significantly lower than the control value for both these groups $(0.005>\mathrm{P}>0.001)$.

Skin Zinc.-Except in the case of pulmonary tuberculosis the skin zinc concentrations were similar whether expressed per 4-mm diameter biopsy specimen or per $\mathrm{g}$ dry weight of skin. There was no significant difference in zinc concentrations between the leprosy patients and the healthy controls and the presence of ulceration did not influence the results (fig.). The skin zinc concentration was unrelated to the presence or absence of a skin smear positive for $M$. leprae or to the clinical type of leprosy. The 16 patients with pulmonary tuberculosis had a mean skin zinc concentration about $50 \%$ higher than that of the healthy controls when expressed per 4-mm biopsy specimen and about $75 \%$ higher when expressed per $g$ dry weight of skin. These differences were highly significant $(0.01>\mathbf{P}>0.005$ and $0.05>\mathbf{P}$ $>0.025$ respectively).

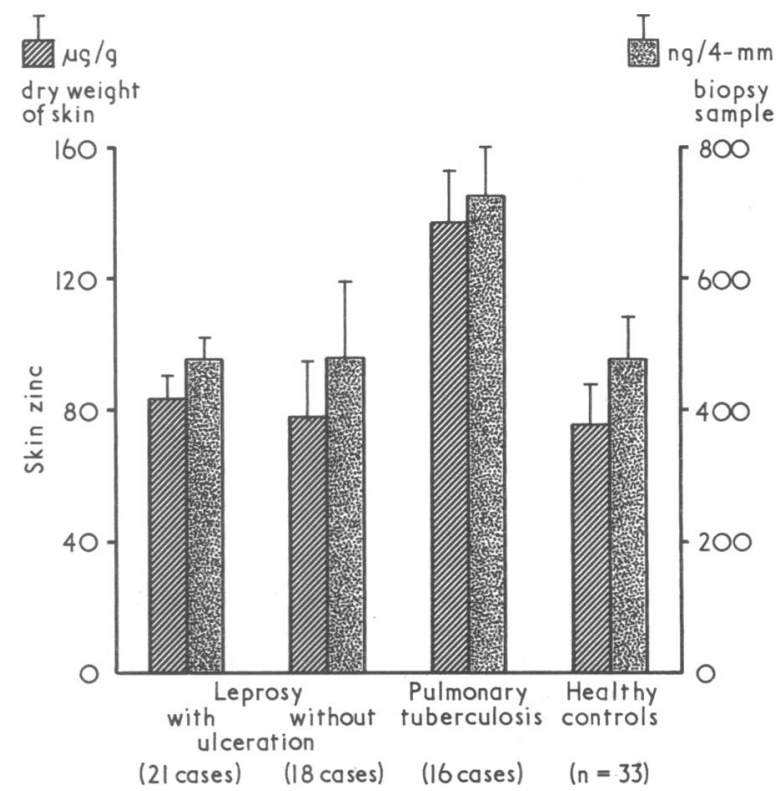

Mean skin zinc concentrations ( \pm S.E. of mean) in leprosy (with and without ulceration) and pulmonary tuberculosis compared with control values.

\section{Discussion}

Our results show that serum zinc concentrations are decreased in leprosy irrespective of the presence or absence of trophic skin ulceration. The significance of this is uncertain, but since decreased serum zinc concentrations were also found in patients with pulmonary tuberculosis, dermatitis herpetiformis, and, in a previous study, other chronic dermatoses (Greaves and Boyde, 1967) the likelihood is that the decreased serum zinc in leprosy is a non-specific metabolic consequence of skin disease (Shuster, 1967).

The results of the concentration of zinc in thigh skin of healthy control subjects were slightly higher than those given previously for abdominal skin (Molokhia and Pontnoy, 1969) and did not differ significantly from results in otherwise comparable subjects with leprosy despite the lowered serum zinc concentrations in leprosy. The zinc content of skin is mainly epidermal (Molokhia and Pontnoy, 1969) and zinc binds to keratin (Strain and Pories, 1966). The avidity of keratin for zinc and the propontion of zinc bound in a metabolically unavailable form in keratin of the stratum corneum remains uncertain. There is experimental evidence that zinc incorporated into epithelial tissues is non-exchangeable and is thus lost to the organism (Pories and Strain, 1970).

The mean serum zinc in the healthy control group agreed with published normal values (Pekarek et al., 1972). The possibility that the lowered serum zinc concentrations which we found in leprosy might be due to reduced binding to one or other fraction of plasma protein cannot be excluded. Zinc is transported in plasma in a protein-bound form (Prasad and Oberleas, 1970; Caughey, 1973). The serum albumin was abnormally low in the leprosy patients but the importance of this in the observed lowering of the serum zinc is uncentain, especially as the propontion of total serum albumin involved in zinc binding may be low. There was no correlation 
between serum albumin and serum zinc in 27 patients with leprosy, and no difference between mean serum albumin values in two groups of leprosy patients with high and low serum zinc concentrations. On the other hand, the serum zinc concentrations were also decreased in patients receiving dapsone for dermatitis herpetiformis. All the leprosy patients were receiving dapsone, and though the protein fractions involved in zinc and dapsone binding are unknown (Prasad and Oberleas, 1970; Weinstein, 1970) competition by dapsone for zinc binding sites on plasma proteins cannot be excluded.

Impaired plasma protein binding is only one of several possible explanations for lowered serum zinc concentrations in leprosy. Experimental evidence suggests that toxaemia of chronic infection causes lowering of the serum zinc, probably as a result of a redistribution of zinc from serum to cells (Pekarek and Beisel, 1969). Toxaemia is not a feature of leprosy and serum zinc concentrations were not dependent on the tissue population of $M$. leprae as reflected in the results of smear examinations. Bacterial toxaemia could, however, be the explanation for the striking findings in pulmonary tuberculosis, in which low serum zinc concentrations coexisted with high skin concentrations. Halstead and Smith (1970) found noticeably lowered serum zinc concentrations in patients with active pulmonary tuberculosis and our findings were similar. Dietary factors may cause a decrease of serum zinc (Rheinold et al., 1973) but are unlikely to have been important in our patients, who were all receiving nutritionally adequate hospital diets.

Though these mechanisms may to varying degrees influence the serum zinc concentration in leprosy the most likely explanation for the decreased serum values is that they are a non-specific metabolic consequence of skin disease, since a similar lowering of serum or plasma zinc concentrations was found in pulmonary tuberculosis in the present study and in psoriasis, venous leg ulceration, and other dermatoses in an earlier investigation (Greaves and Boyde, 1967). Shuster and Marks (1970) highlighted the varied metabolic costs of skin disease, which include lowering of the serum iron, folate deficiency, and hypoalbuminaemia, and it seems probable that lowered serum zinc should be added to the list. The presumed non-specific nature of the decreased serum zinc in trophic skin ulceration of leprosy does not, however, exclude the possibility that zinc may be a limiting factor in the rate of healing of the ulcers, and it is of interest that in leg ulceration from other causes also associated with decreased serum zinc concentrations a beneficial effeot of systemic zinc treatment has been claimed (Husain, 1969; Serjeant et al., 1970; Hallbook and Lanner, 1972).

This work was supported by a grant from the Nuffield Foundation to $\mathrm{M}$. W. Greaves. Other financial aid was provided by $\mathrm{Mr}$. R. J. Hulse, Medo-Chemicals Ltd., London. We are also grateful to the Director of Medical Services, Ministry of Health, Singapore; Dr. V. S. Rajan, Middle Road Hospital; and Dr. Ng Yook Kim, Tan Tock -Seng Hospital, for providing facilities. We thank Professor Sam Shuster for helpful comments. Miss Maureen Davison, Mr. Ng Bee Tong, and Mr. Jim Gossop gave excellent technical help.

\section{References}

Caughey, J. E. (1973). Lancet, 2, 376.

Documenta Geigy (1970). Scientific Tables, 7th edn., p. 553. Macclesfield, Geigy (U.K.) Pharmaceuticals.

Greaves, M. W., and Boyde, T. R. C. (1967). Lancet, 2, 1019.

Hallbook, T., and Lanner, E. (1972). Lancet, 2, 780.

Halstead, J. A., and Smith, J. C. (1970). Lancet, 1, 322.

Harrison, W. W., Netsky, M. G., and Brown, M. D. (1968). Clinica Chimica Acta, 21, 55

Husain, S. L. (1969). Lancet, 1, 1069.

Molokhia, M. M., and Portnoy, B. (1969). British fournal of Dermatology, 81, 759 .

Pekarek, R. S., and Beisel, W. R. (1969). Applied Microbiology, 18, 482.

Pekarek, R. S., Beisel, W. R., Bartelloni, P. J., and Bostian, K. A. (1972).

American fournal of Clinical Pathology, 57,506 .
Pories, W. J., and Strain, W. H. (1970). In Trace Element Metabolism in Animals, ed. C. F. Mills, p. 75 . Edinburgh, Livingstone.
A

Animals, ed. C. F. Mils, p. 75. Edinburgh, Livingstone.
Prasad, A. S., and Oberleas, D. (1970). Fournal of Laboratory and Clinical Medicine, 76, 416.

Rheinold, F. G., Nasr, K., Lahimgarzadeh, A., and Hedayati, H. (1973). Lancet, $1,283$.

Serjeant, G. R., Galloway, R. E., and Gueri, M. C. (1970). Lancet, 2, 891.

Shuster, S. (1967). Lancet, 1, 907.

Shuster, S., and Bottoms, Eva (1963). Clinical Science, 25, 487.

Shuster, S., and Marks, Janet (1970). Systemic Effects of Skin Disease. London, Heinemann.

Shuster, S., Raffle, E. J., and Bottoms, Eva (1967). Lancet, 1, 525.

Strain, W. H., and Pories, W. J. (1966). In Zinc Metabolism, ed. A. S. Prasad,

p. 363. Springfield, Thomas.
Weinstein, L. (1970). In The Pharmacological Basis of Therapeutics, ed. L. S. Goodman and A. Gilman, 4th edn., p. 1311. London, Macmillan

Withers, A. F. D., Baker, H., Musa, M., and Dormandy, T. L. (1968). Lancet, 2, 278 .

\title{
Eye Defects of Mentally Handicapped Children
}

\author{
J. L. KENNERLEY BANKES
}

British Medical fournal, 1974, 2, 533-535

\section{Summary}

Among 171 children who received routine ophthalmic and orthoptic examinations as part of their evaluation for suspected or known developmental handicap it was found that there was an unusually high incidence of ocular defects. Especially prevalent were high refractive errors $(52 \%)$ and squints $(40 \%)$, but there were also a number of other serious eye defects ranging from nystagmus and cataracts to microphthalmos.

Because of this high incidence of eye defects it was considered essential that ophthalmic and orthoptic

St. Mary's Hospital, London W2 1NY

J. L. KENNERLEY BANKES, D.o., F.R.C.S., Consultant Ophthalmic Surgeon examinations should be part of the routine evaluation of developmentally handicapped children by the team of workers in an assessment centre.

\section{Assessment Centre}

Routine ophthalmic examination of known or suspected mentally handicapped children is still very far from being standard practice. The purpose of this paper is to emphasize the need for full ophthalmic and orthoptic evaluation of mentally handicapped children as part of the routine examination of an assessment centre team. Such an assessment centre team of workers has been working together for some four years at St. Mary's Hospital, London, in the children's department. The team consists of the following members: a consultant paediatrician, another paediatrician, who is also principal medical officer for Westminster City Council, a consultant ophthalmic surgeon, an audiologist, who is a senior registrar, an orthoptist, an audio- 